www.czasopisma.marszalek.com.pl/pl/10-15804/npw

\title{
PIOTR ZARICZNY
}

Państwowa Uczelnia Zawodowa we Włocławku

ORCID ID: https://orcid.org/0000-0003-0158-4303

\section{Reformy w Europie Centralnej - nowy porządek na Starym Kontynencie?}

[recenzja książki Die neue Ordnung auf dem alten Kontinent.

Eine Geschichte des neoliberalen Europa]

\section{Reforms in Central Europe - a new order on the Old Continent?}

[book review Die neue Ordnung auf dem alten Kontinent. Eine Geschichte des neoliberalen Europa]

Реформы в Центральной Европе новый порядок на Старом континенте?

[рецензия книги Die neue Ordnung auf dem alten Kontinent. Eine Geschichte des neoliberalen Europa]

7 nakomity niemiecki badacz Wilhelm von Humboldt powiedział onegdaj: „Tylko ci, którzy znają przeszłość, mają przyszłość”. Znajomość przeszłości to umiejętność orientowania się w teraźniejszości. Pytanie brzmi, jaką przeszłość powinniśmy znać, aby się orientować: lokalną, regionalną czy paneuropejską? Dziś wiedza o historii regionu czy kraju nie wystarczy, by poznać własną kulturę, wzmocnić procesy demokratyzacji i uczynić je przyszłościowymi. Praca Philippa Thera doskonale wpisuje się zarówno w powyższą myśl, jak i trend upraktycznienia oraz popularyzacji nauki.

Wiedeński historyk Philipp Ther namalował naukowym piórem na 432 stronicach obraz reform polityczno-gospodarczych, które miały wprowadzić 
nowy porządek na Starym Kontynencie po 1989 roku. Największe wrażenie w książce robi ogromna liczba faktów i ich staranne ułożenie, a także jasny, płynny styl autora, który sprawia, że ten akademicki produkt jest łatwy do zrozumienia nawet dla nieakademickiego odbiorcy. Kiedy w listopadzie 1989 roku upadł mur, rozpoczął się zakrojony na szeroką skalę eksperyment o wymiarze kontynentalnym: dawne państwa bloku wschodniego zostały szybko przyjęte i przycięte do neoliberalnego porządku oraz poddane reżimowi prywatyzacji i liberalizacji. Philipp Ther był na miejscu, gdy ludzie wychodzili wówczas na ulice Pragi, później przez kilka lat mieszkał w Czechach, Polsce i na Ukrainie. W książce tej przedstawia kompleksową współczesną analizę historyczną nowego ładu w Europie - po raz pierwszy w perspektywie paneuropejskiej. Wzbogacony o osobiste doświadczenia autora tekst podsumowuje przebieg tzw. „negocjowanych rewolucji”. Pokazuje, że restrukturyzacja gospodarek Europy Środkowej i Wschodniej miała również wpływ na kraje Zachodu. Reformy rynku pracy federalnego rządu Czerwono-Zielonych interpretuje on $\mathrm{np}$. jako modernizację bumerangową.

Autor próbuje zlikwidować niektóre mity opisujące dotychczas prawie legendarny 1989 rok i stawia odważne pytania. Co zadziałało lepiej - radykalna terapia szokowa czy stopniowe reformy? Jakie wnioski można wyciągnąć przyglądając się dzisiaj obecnemu kryzysowi politycznemu w takich państwach jak Polska czy Węgry lub kryzysowi gospodarczemu w krajach Europy Południowej, m.in. we Włoszech, Hiszpanii czy Grecji? I dlaczego Berlin został ekonomicznie wyprzedzony przez takie miasta, jak Warszawa czy Praga?

Neoliberalizm był jak błyszczący pociąg ekspresowy, w którym obiecywano wzrost i dobrobyt. Wszystkie państwa europejskie chciały od pewnego czasu wejść do tego pociągu, nikt nie mógł uciec od jego blasku i siły przyciągania. Podróżnym robiło się czasami niedobrze od prędkości jazdy i receptur reform, które musieli przyjąć, ale od połowy lat 90. poczuli się nieco lepiej. Konduktor i kelner w wagonie restauracyjnym pokrzykiwali głośno i często, że terapia szokowa zadziałała. Pasażerowie spotykali się kilka razy dziennie w wagonie restauracyjnym, gdzie było tylko jedno danie, serwowane przez kelnerów z Zachodu. Pasażerowie w rzeczywistości nie zawsze chcieli jeść to danie, ale czuli siłę i moc kelnerów, którzy w każdej chwili mogli żądać oddania starych długów. Wydawało się, że mają oni monopol na mądrość gospodarczą. Wars wita was. Ten Wars to było znakomite miejsce do wygłaszania górnolotnych 
przemówień na temat reform. Kelnerzy powtarzali jak mantrę frazy o prywatyzacji, liberalizacji, deregulacji. Coś w rodzaju modlitwy.

Ale Anno Domini 2008 pociąg ekspresowy prawie się wykoleił. Wśród pracowników, kelnerów i podróżnych wybuchła panika, wszyscy byli niepewni co do dalszego kierunku jazdy pociągu. No i w okresie największej bezradności z pociągu wysiadł jeden $\mathrm{z}$ najznakomitszych gości o imieniu Władimir Władimirowicz i spróbował umieścić w torach własny pociąg, na którego lokomotywie pojawił się dumny napis „Euroazjatycka Unia Gospodarcza”. Teraz próbuje on z całych sił wciągnąć do tego pociągu swoich sąsiadów. Rywalizacja pomiędzy tymi dwoma pociągami pozostaje na razie nierozstrzygnięta.

Sama metafora może wywołać podwójne zainteresowanie: obiecuje ona nie tylko innowacyjną europejską perspektywę współczesnej historii, lecz także jedną z pierwszych syntez historycznych dotyczących neoliberalizmu.

Opowieść zaczyna teza ogólnoeuropejska: w ciągu dziesięcioleci po 1989 roku doszło do kotransformacji, podczas których neoliberalne reformy migrowały ze wschodu na zachód. W byłym NRD zanotowano najszybszy i najbardziej radykalny kurs oraz „terapię szokową”. Gospodarka i społeczeństwo w byłej NRD były najbardziej otwarte na Zachód, ale zostały one uchwycone w znacznym stopniu przez zachodnioniemieckie państwo opiekuńcze. Następnie mieliśmy dość radykalne reformy w Polsce i w Czechach. Ponieważ demokracje tamtejsze nie były jeszcze szeroko rozwinięte, neoliberalne reformy mogły być realizowane w stosunku do opinii publicznej stosunkowo łatwo. Jednak już w sezonie 1993-1994 reformy zostały wyhamowane po sukcesie postkomunistycznych socjaldemokratów w Polsce, ale również poprzez zmiany prawne w Republice Czeskiej. Te zmiany skontrastować można z mniej udanym rozwojem gospodarczym w państwach takich jak Rumunia, Bułgaria czy Ukraina, gdzie odstąpiono od odpowiednich deregulacji i postkomunistyczne rządy nie opanowały procesu reform. Kwintesencją tego porównania jest to, że neoliberalne reformy w Europie Środkowej i Wschodniej były wtedy udane, kiedy zostały opanowane przez państwowe ramy regulacyjne. Neoliberalizm zdany jest na silne państwo, czyli pomoc państwa w zakresie edukacji, równości społecznej lub ram prawnych. Reformy dotykały wiele krajów - ale obok różnic narodowościowych i wewnątrzpaństwowych duże rozbieżności zachodziły między obszarami miejskimi i wiejskimi - za 
ciekawy przykład może służyć Polska i Warszawa. One są w szczególności w centrum. Warszawa jest swoistym Boomtown Europy Centralnej z najbardziej dynamicznym rynkiem pracy. W przypadku Polski warto podkreślić silną transformację od dołu, z ogromnym rozwojem małych i średnich firm oraz tętniącym życiem barterem, nie tylko na bazarach. W przeciwieństwie do Wiednia i Pragi, Berlin na przykład nie docenił szans na otwarcie się Europy i nie promował inicjatywy własnej, przyjął wzorzec z Bonn, czyli od góry. Tę perspektywę oddolną można uzupełnić spojrzeniem na rolę często krytykowanej Unii Europejskiej. UE to nie tylko aktor neoliberalnych reform, ale też inicjator polityki finansowej od 1989 roku, a w szczególności od 2004 roku. Sukces środków unijnych inwestowanych na wschodzie od Brukseli zdecydowanie przerósł zarówno w kategoriach bezwzględnych, jak i w stosunku do produktu krajowego brutto państw beneficjentów adekwatne środki z powojennego planu Marshalla oraz ich efektywność gospodarczą.

Po krótkim okresie transformacji w państwach postkomunistycznych nastąpiło w całej Europie zwalczanie skutków kryzysu finansowego z 2008 roku. Podczas gdy większość opinii publicznej w Europie Zachodniej bardziej interesowała się Grecją, Włochami, Hiszpanią czy Irlandią, należy wskazać na katastrofalne konsekwencje kryzysu dla Europy Środkowej, na co zareagowano keynesowskim sterowaniem. Po krótkim okresie zbliżania się Wschodu do Zachodu nastąpiło ograniczenie przepływów pieniężnych i inwestycji zagranicznych. Jednak ta bańka i tak wkrótce pękła, czego efekt mamy np. w Polsce w 2015 roku. Oczywiście bez środków z UE i oszczędzania państwa Europy Środkowej i Wschodniej mogłyby sobie nie poradzić z kryzysem. Jednak przestrzeganie umiarkowanych reform i fakt, że stopień inwestycji transatlantyckich też był umiarkowany, uratowało to np. Polskę od całkowitego wykolejenia. Po długim okresie konfrontacji i asymetrii Wschód-Zachód oraz po kryzysie rozpoczętym w 2008 roku widać teraz nową asymetrię w Europie, mianowicie północ-południe i można postawić tezę o Południu jako nowym Wschodzie Europy. Włochy nie były w stanie otworzyć się produktywnie w kierunku wschodnim. Generalnie wielu wschodnich Europejczyków w pewnym stopniu zahartowanych przez neoliberalizm jest dziś znacznie bardziej mobilnych i elastycznych niż południowi Europejczycy. Wreszcie Republika Federalna Niemiec jest przykładem odnośnie wstępnej hipotezy o kotransformacji. Prywatyzacja systemu emerytur, ale przede wszystkim reformy społeczne 
i rynku pracy po 2004 roku były pewną reakcją w odpowiedzi na zmiany u wschodnich sąsiadów po rozszerzeniu UE. Oczywiście możemy zapytać, w jakim stopniu pojęcie „neoliberalny” jest rzeczywiście trafną etykietą dla Europy po roku 1989/1990. Powyżej sam raczej pokazałem granice neoliberalnych reform. Pomimo hegemonii neoliberalizmu, w praktyce politycznej reformy w Europie Środkowo-Wschodniej i w Polsce zawsze odbiegały od czystej doktryny. Moje wstępne porównanie neoliberalizmu z pociągiem ekspresowym, do którego wiele państw wsiadło po 1990 roku i który prawie się wykoleił w wyniku przyspieszenia w 2008 roku, jest satyrą i prowokacją w jednym. Pociąg jednak wciąż nie zmienił kierunku jazdy, poza jednym pasażerem. Ta metafora wydaje się nieco sztywna. Być może lepiej to odnieść do obrazu autostrady: państwa europejskie wybrały bardzo różne tempo i środki transportu; niektórzy ucierpieli w wypadkach przez szybkie wyprzedzanie, inni osiągnęli swoje cele wolniej i późno lub pozostali na parkingach lub w ślepych uliczkach, gdyż mimo podstawowej hegemonii ideologicznej także w polityce gospodarczej możliwe były specyficzne jej modyfikacje i odgałęzienia lub ich zaniechanie.

Z neoliberalizmem jest trochę tak, jak z pornografią - trudno go zdefiniować, łatwiej zobaczyć. Jak się obserwuje, to widać np. iskrzący obietnicami wzrostu i dobrobytu pociąg ekspresowy. Analiza pokazuje klucz do rozpoznania hegemonii, w tym przypadku nazwanej jako neoliberalna. Pomimo nieostrości terminologicznej i koncepcyjnej dwuznaczności klucz ten może pomóc wyjaśnić niejedno zjawisko (porażki i sukcesy) procesu transformacji systemowej w Europie Środkowo-Wschodniej i funkcji narracji hegemonialnej.

DR HAB. PIOTR ZARICZNY, PROF. PUZ

Zakład Nowych Mediów

Instytut Humanistyczny

Państwowa Uczelnia Zawodowa we Włocławku

ul. Mechaników 3, 87-800 Włocławek

piotr.zariczny@pwsz.wloclawek.pl

\section{Bibliografia}

Ther, P. (2016). Die neue Ordnung auf dem alten Kontinent. Eine Geschichte des neoliberalen Europa. Berlin: Suhrkamp Verlag. 